\title{
Pathogenicity of Mycolicibacterium phlei, a non-pathogenic nontuberculous mycobacterium in an immunocompetent host carrying anti-interferon gamma autoantibodies: a case report
}

\author{
Satomi Tanaka ${ }^{1 *}$ (D) Y Yoshihiko Hoshino ${ }^{2}$, Takuro Sakagami ${ }^{3}$, Hanako Fukano $^{2}$, Yohei Matsui ${ }^{1}$ and Osamu Hiranuma ${ }^{1}$
}

\begin{abstract}
Background: Mycolicibacterium phlei (M. phlei) is known to be a non-pathogenic nontuberculous mycobacterium (NTM) which rarely causes diseases in humans. A disseminated NTM infection is mostly caused by the Mycobacterium avium complex (MAC) and is known to develop in immunocompromised hosts, like those with acquired immune deficiency syndrome (AIDS). Here, we report a case of disseminated M. phlei infection in an immunocompetent host carrying anti-interferon gamma (IFN- $\gamma$ ) autoantibodies.

Case presentation: We detected M. phlei in multiple organs of an elderly woman with no significant medical history except positivity for anti-IFN- $\gamma$ autoantibodies. She tested negative for human immunodeficiency virus (HIV)1, 2/ Human T-cell leukemia virus type 1 (HTLV-1) antibody. High-resolution computed tomography (HRCT) of the chest demonstrated a nodule in the left S1 + 2 segment, interlobular septal thickening, multi lymphadenopathy, and osteolysis. A maximum intensity projection image following fluorodeoxyglucose-positron emission tomography (FDG-PET) revealed multifocal hypermetabolic lesions in the nodule and all the swollen lymph nodes seen in HRCT. FDG also accumulated in multiple bones. Advanced primary lung cancer was suspected, and biopsies of each lesion were performed. The pathology revealed caseating granuloma, positive for acid-fast bacteria, and DNA sequencing of the acid-fast bacteria confirmed the organism to be M. phlei. The patient also tested positive for anti-IFN- $\gamma$ autoantibodies. Based on these findings, she was diagnosed with disseminated M. phlei infection, with anti-IFN- $\gamma$ autoantibodies.
\end{abstract}

Conclusions: Though known to be non-pathogenic, we show that M. phlei can be pathogenic like the MAC in immunocompetent individuals carrying anti-IFN- $\gamma$ autoantibodies.

Keywords: Disseminated infection, M. phlei , Autoantibody, Interferon gamma

\footnotetext{
* Correspondence: satanaka@koto.kpu-m.ac.jp

Otsu City Hospital, 2-9-9, Motomiya, Otsu-city, Shiga Prefecture, Japan

Full list of author information is available at the end of the article
}

(c) The Author(s). 2019 Open Access This article is distributed under the terms of the Creative Commons Attribution 4.0 International License (http://creativecommons.org/licenses/by/4.0/), which permits unrestricted use, distribution, and reproduction in any medium, provided you give appropriate credit to the original author(s) and the source, provide a link to the Creative Commons license, and indicate if changes were made. The Creative Commons Public Domain Dedication waiver (http://creativecommons.org/publicdomain/zero/1.0/) applies to the data made available in this article, unless otherwise stated. 


\section{Case report}

\section{Background}

Disseminated nontuberculous mycobacterium (NTM) infection is a disease that primarily occurs in immunocompromised hosts, such as those with acquired immune deficiency syndrome (AIDS). However recently some reports on disseminated NTM infection in immunocompetent hosts have been published, and most of them carry anti-interferon gamma (IFN- $\gamma$ ) autoantibodies [1]. Almost all of these cases of NTM involve Mycobacterium avium complex (MAC) or other pathogenic NTM.

Mycolicibacterium Phlei (M. phlei) is classified as a non-pathogenic NTM [1]. While there are very few reports of $M$. phlei causing infections in humans [2-8], there are none of it causing disseminated infections. Based on its non-pathogenicity, $M$. phlei has been used for the treatment of conditions like asthma [9].

Here, we report a case of disseminated M. phlei infection in an immunocompetent host carrying anti-IFN- $\gamma$ autoantibodies. It is possible that the pathogenicity of $M$. phlei in such hosts is different from that in hosts with a normal immune system.

\section{Case presentation}

A 79-year-old woman with no significant medical history visited the Otsu City Hospital (Shiga prefecture, Japan) complaining of chest pain that had persisted for the last one month. Her vital signs were normal, and except for diffuse erythema with lichenification of the trunk and limbs, the physical examination was unremarkable. The initial laboratory data indicated a high level of inflammation with a white blood cell count (WBC) of $18,100 / \mu \mathrm{L}$ (normal range: 3800-9400/ $\mu \mathrm{L}$ ), c-reactive protein (CRP) levels of $7.56 \mathrm{mg} / \mathrm{dL}(0.00-0.03 \mathrm{mg} / \mathrm{dL})$, and an erythrocyte sedimentation rate (ESR) of $136 \mathrm{~mm} / \mathrm{h}(1.0-15.0$ $\mathrm{mm} / \mathrm{h}$ ). She tested negative for human immunodeficiency virus (HIV)-1, 2/ Human T-cell leukemia virus type 1 (HTLV-1) antibody. QuantiFERON-Gold in tube (QFT) yielded indeterminate results. She tested negative for MAC infection, based on the serum levels of anti-glycopeptidolipid-core immunoglobulin (Capilia MAC Antibody ELISA) ${ }^{\circ}$ [10]. The levels of immunoglobulin G (IgG), IgA, IgM were normal (Table 1). High-resolution computed tomography (HRCT) of the chest demonstrated a nodule in the left $\mathrm{S} 1+2$ segment, interlobular septal thickening in the left lower lobe, lymphadenopathy of the left hilar, mediastinal, supraclavicular, and posterior cervical lymph nodes, and osteolysis of the sternum and the left second rib, which might have caused the chest pain. She also had hepatosplenomegaly. A maximum intensity projection image following fluorodeoxyglucose-positron emission tomography (FDG-PET) revealed multifocal hypermetabolic lesions in the nodule and all the swollen lymph nodes seen in HRCT. FDG also accumulated in the anterior spinal cord, sacrum, iliac bone, pubic bone,

Table 1 The laboratory data, initial and 2 years after

\begin{tabular}{|c|c|c|c|c|c|c|c|c|}
\hline \multicolumn{3}{|c|}{ Hematology (initial) } & \multicolumn{6}{|c|}{ Biochemistry (initial) } \\
\hline WBC & 18,100 & $/ \mu \mathrm{L}$ & $\mathrm{TP}$ & 6.9 & $\mathrm{~g} / \mathrm{dL}$ & CEA & 2.6 & $\mathrm{ng} / \mathrm{mL}$ \\
\hline Neut & 69.5 & $\%$ & Alb & 2.8 & $\mathrm{~g} / \mathrm{dL}$ & $\mathrm{SCC}$ & 0.9 & $\mathrm{ng} / \mathrm{mL}$ \\
\hline Eos & 16 & $\%$ & AST & 9 & $U / L$ & NSE & 10.3 & $\mathrm{ng} / \mathrm{mL}$ \\
\hline Lym & 11 & $\%$ & $\mathrm{ALT}$ & 16 & $U / L$ & ProGRP & 33.9 & $\mathrm{pg} / \mathrm{mL}$ \\
\hline $\mathrm{Hb}$ & 8.9 & $\mathrm{~g} / \mathrm{dL}$ & $\mathrm{LDH}$ & 192 & $U / L$ & CYFRA & 1.6 & $\mathrm{ng} / \mathrm{mL}$ \\
\hline $\mathrm{Ht}$ & 27.2 & $\%$ & ALP & 522 & $U / L$ & CA19-9 & 5 & $\mathrm{U} / \mathrm{mL}$ \\
\hline MCV & 86.3 & $\mu \mathrm{m} 3$ & Y-GTP & 79 & $U / L$ & $S I L-2 R$ & 10,252 & $\mathrm{U} / \mathrm{mL}$ \\
\hline $\mathrm{MCHC}$ & 32.7 & $\%$ & CK & 16 & $U / L$ & HTLV-1 antibody & $<16$ & times \\
\hline Plt & 375,000 & $/ \mu \mathrm{L}$ & $\mathrm{Na}$ & 138 & $\mathrm{mEq} / \mathrm{L}$ & $\mathrm{T}_{-\mathrm{SPOT}}$ & $(-)$ & \\
\hline \multirow[t]{2}{*}{ ESR } & 136 & $\mathrm{~mm} / \mathrm{h}$ & K & 4.5 & $\mathrm{mEq} / \mathrm{L}$ & QuantiFERON & $<0.05$ & \\
\hline & & & $\mathrm{Cl}$ & 102 & $\mathrm{mEq} / \mathrm{L}$ & & & undeterminate \\
\hline \multirow[t]{2}{*}{ (2 years after) } & & & BUN & 23 & $\mathrm{mg} / \mathrm{dL}$ & Capillia MAC IgA & $(-)$ & \\
\hline & & & CRE & 0.93 & $\mathrm{mg} / \mathrm{dL}$ & $\lg G$ & 1072 & $\mathrm{mg} / \mathrm{dL}$ \\
\hline WBC & 7400 & $/ \mu \mathrm{L}$ & Blood Sugar & 106 & $\mathrm{mg} / \mathrm{dL}$ & $\lg A$ & 144 & $\mathrm{mg} / \mathrm{dL}$ \\
\hline Lym & 20.4 & $\%$ & CRP & 7.56 & $\mathrm{mg} / \mathrm{dL}$ & $\lg M$ & 61 & $\mathrm{mg} / \mathrm{dL}$ \\
\hline CD4 & 30.7 & $\%$ & $\mathrm{PCT}$ & 0.43 & $\mathrm{ng} / \mathrm{mL}$ & HIV-1/2 antibodies & $(-/-)$ & \\
\hline CD8 & 39.7 & $\%$ & $\beta-D$ glucan & $<2.4$ & $\mathrm{pg} / \mathrm{mL}$ & & & \\
\hline CD4/CD8 & 0.8 & & & & & PHA SI & 528.4 & \\
\hline
\end{tabular}

PCT procalcitonin, CEA carcinoembryonic antigen, SCC Squamous Cell Carcinoma, CYFRA cytokeratin 19 fragment, NSE nerve specific enolase, Pro GRP pro-gastrin releasing peptide, CA19-9 carbohydrate antigen 19-9, s/L-2R soluble interleukin-2 receptor, PHA SI the lymphocyte phytohemagglutinin (PHA) stimulation index 
ischium, sternum, scapula, ribs, clavicle, and thigh bone (Fig. 1).

Magnetic resonance imaging (MRI) of the lumbar to thoracic vertebrae was performed. Based on a T2-weighted image showing a mottled abnormal signal, bone marrow infiltration or necrosis was suspected.

Advanced primary lung cancer was suspected, and a cervical lymph node biopsy was performed. The pathology revealed a caseating granuloma, positive for acid-fast bacteria. We performed the left iliac bone marrow and transbronchial lung biopsies (TBLB). While the

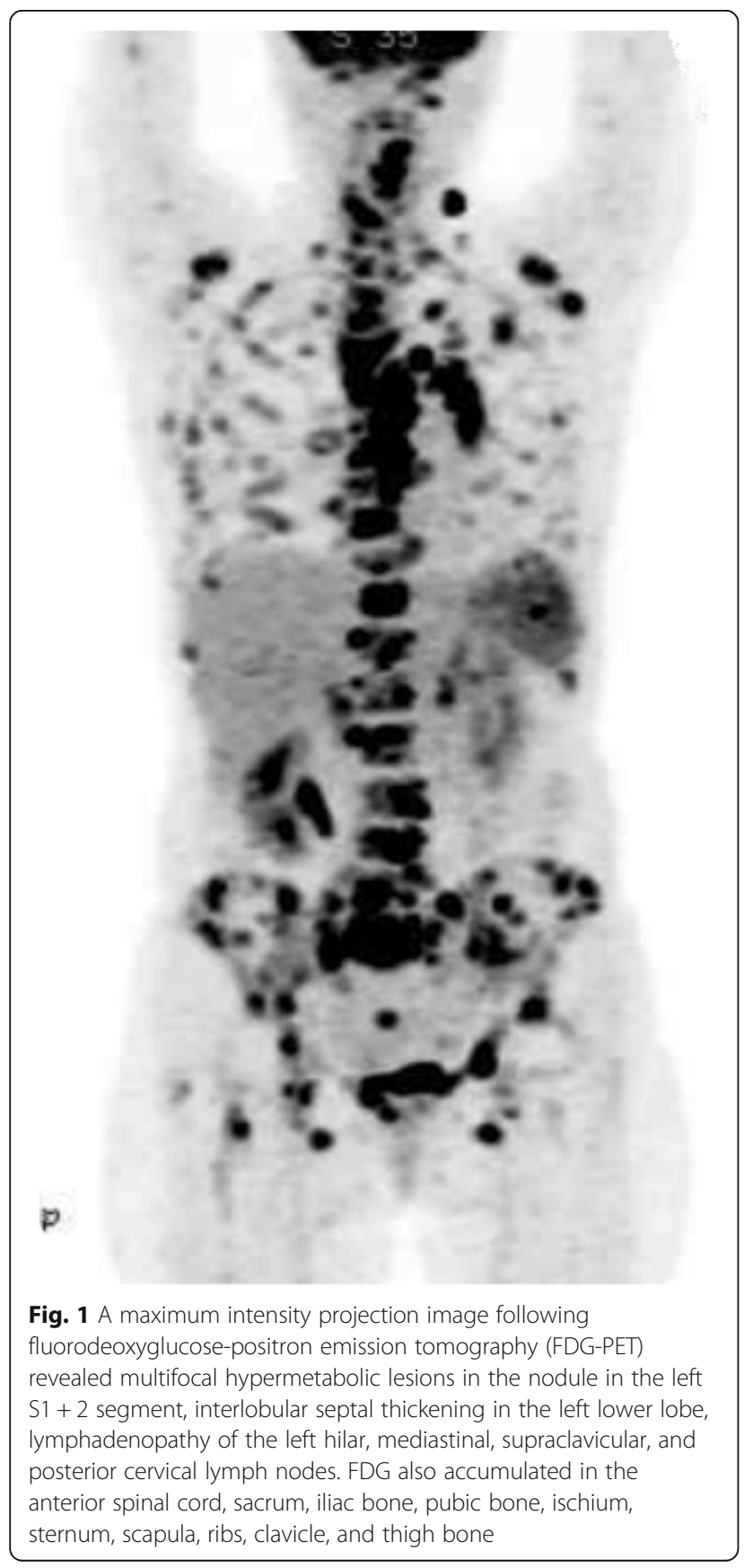

bone marrow biopsy revealed tiny granulomas, no special findings were seen in TBLB. Since there was no evidence of malignancy, video-assisted thoracic surgery was performed for confirmation. The nodule in the left $\mathrm{S} 1+$ 2 segment on HRCT could not be identified directly, and therefore, biopsies of the para-aortic, swollen lymph node and pleura were performed instead. The biopsies revealed epithelioid granuloma, which stained positive for acid-fast bacteria. The real time -polymerase chain reaction was negative for tuberculosis or MAC. The number of acid-fast bacteria on the biopsy specimens was so low that no pathogen was detected after their culture. From these results, it was concluded that she had disseminated NTM infection, even though she had no history of being immunocompromised except for the indeterminate $\mathrm{QFT}^{\circ}$ results.

She was started on a multi-drug combination therapy which included rifampicin $300 \mathrm{mg} /$ day, ethambutol 500 $\mathrm{mg} /$ day, clarithromycin $600 \mathrm{mg} /$ day, and levofloxacin $300 \mathrm{mg} /$ day. Because the sputum test was negative for mycobacterium based on the Ziehl-Neelsen staining, the follow up was based on her ESR and CRP levels, both of which improved gradually. Since we did not culture blood for acid-fast bacteria and no pathogens were detected following the culture of the biopsy specimens, we recovered the genome of the bacteria from the paraffin blocks. The partial nucleotide sequences of the $h s p 65$ and $r p o B$ genes were amplified and sequenced. DNA sequencing confirmed the organism to be $M$. phlei. We concluded she had IFN- $\gamma$ autoantibody, because her serum retained high concentration of neutralizing capacity to IFN- $\gamma$, measured by flow-cytometry based method and the antigen capture assay formerly described [11]. Based on these results, we evaluated the levels of CD4 and CD8, as well as the lymphocyte phytohemagglutinin (PHA) stimulation index to assess her cell-mediated immunity. She had 30.7\% (463/ $\mu \mathrm{L}) \mathrm{CD} 4$ (normal range: $25.0-54.0 \%$ ) and $39.7 \%$ CD 8 (23.0$56.0 \%)$. The CD4:CD8 ratio was $0.8(0.40-2.30)$, and the lymphocyte PHA stimulation index was 528.4 (101.62643.8). Her cell-mediated immunity was normal. Following the completion of treatment in 26 months, her ESR levels normalized. The swelling in the lymph nodes and the abnormal vertebral lesions showed improvement. Following-ups are ongoing (Fig. 2).

\section{Discussion and conclusions}

Anti IFN- $\gamma$ autoantibodies are associated with adult-onset of immunodeficiency akin to that seen in patients with acquired immunodeficiency syndrome (AIDS). These antibodies can cause disseminated NTM infections in an immunocompetent host, which was previously known to occur only AIDS patients [1]. The presence of these antibodies has been associated with 


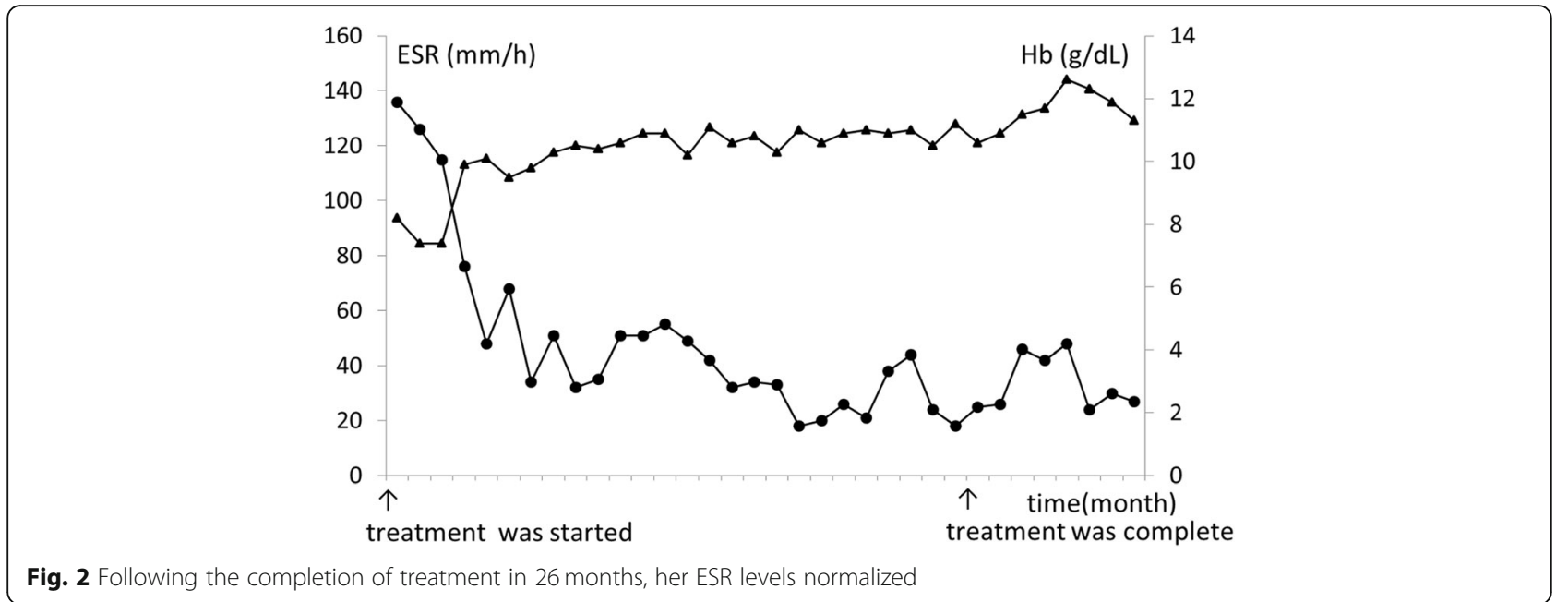

disseminated NTM mostly caused by pathogenic NTM, except in the case of $M$. mantenii infections, the virulence of which has never been clearly demonstrated [12].

M. phlei belongs to the Runyon's classification group IV of rapidly growing potential pathogens [13], but the American Thoracic Society does not list it as a pathogenic mycobacterium [14]. The molecular basis for the virulence of the mycobacterium species is still not well understood. Studies on M. phlei by Beltan et al. [15] have suggested that important differences exist between pathogenic and non-pathogenic mycobacterium species, particularly with respect to TNF- $\alpha$ and GM-CSF signalling. Raynaud et al. [16] have reported the role of extracellular enzymes in the pathogenicity of mycobacterium species. Twenty-two enzyme activities were detected from the culture fluids and/or cell surfaces of mycobacterium species, of which eight were absent from the culture fluids of non-pathogens. They have also suggested that the molecular architecture of the mycobacterial envelopes may play an important role in the pathogenicity of these organisms. These studies support the non-pathogenicity of $M$. phlei. Based on its non-pathogenicity in humans, M. phlei has been used for the treatment of conditions like asthma. The inhalation of it can reduce airway inflammation by regulating IL-4, IL-10, and IFN- $\gamma$ secretion [9]. Reports on $M$. phlei infections are extremely rare, with eight cases reported as per our search (Table 2) [2$8]$. The case reported here is the ninth case, but the first one to describe a disseminated form of the infection. Almost all of the reported infections were in immunocompetent hosts, except for the eighth one wherein the patient had AIDS. However, in this case, the patient had a normal X-ray, and the sputum test

Table 2 Reports on M. phlei infections

\begin{tabular}{|c|c|c|c|c|c|c|}
\hline $\begin{array}{l}\text { No. } \\
\text { [Reference] }\end{array}$ & $\begin{array}{l}\text { Age } \\
\text { /Gender }\end{array}$ & Infected Organs & Background & $\begin{array}{l}\text { Immuno- } \\
\text { suppressive drug }\end{array}$ & Medication & $\begin{array}{l}\text { Duration of therapy/ } \\
\text { clinical outcome }\end{array}$ \\
\hline 1. [2] & $7 / M$ & synovial fluid and tissue & healthy & none & INH, RFP, and SM & 9 month/cured \\
\hline 2. [3] & $49 / M$ & $\begin{array}{l}\text { flexor digitorum longus and posterior tibialis } \\
\text { tendon of his right foot. }\end{array}$ & healthy & none & CAM and CPFX & 2 month/cured \\
\hline 3. [4] & $17 / M$ & peritonitis & $\begin{array}{l}\text { CAPD due to } \\
\text { FSGS }\end{array}$ & none & $\begin{array}{l}\text { AMK, CFX and } \\
\text { DOXY }\end{array}$ & 9 month/cured \\
\hline 4. [5] & $73 / F$ & pacemaker infection & $\begin{array}{l}\text { ICM(NYHAIII), DM, } \\
\text { HT }\end{array}$ & none & DOXY & 12 month/cured \\
\hline 5. [6] & N/A & lung & healthy & none & N/A & N/A \\
\hline 6. [6] & N/A & lung & healthy & none & N/A & N/A \\
\hline 7. [7] & N/A & lung & N/A & N/A & N/A & N/A \\
\hline 8. [8] & $35 / M$ & None (colonization) & 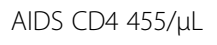 & N/A & N/A & N/A \\
\hline This case & $79 / F$ & Lung, lymph nodes, multiple bones & $\begin{array}{l}\text { anti-IFN- } \gamma \\
\text { autoantibodies }\end{array}$ & none & $\begin{array}{l}\text { RFP, EB, CAM, } \\
\text { and LVFX }\end{array}$ & 26 month/cured \\
\hline
\end{tabular}

N/A not available, CAPD Continuous ambulatory peritoneal dialysis, FSGS focal and segmental glomerulosclerosis, ICM Ischemic cardiomyopathy, NYHA New York Heart Association, DM diabetes mellitus, HT hypertension, AIDS Acquired immune deficiency syndrome, INH Isoniazid, RFP Rifampin, SM Streptomycin, CAM Clarithromycin, CPFX Ciprofloxin, AMK Amikacin, CFX Cefoxitin, DOXY Doxycycline, EB Ethambutol, LVFX Levofloxacin 
was positive for $M$. phlei only once, suggesting mere colonization rather than a pathogenic role.

The patient in our study also had no significant medical or drug history, except positivity for anti-IFN- $\gamma$ autoantibodies. To understand why this non-pathogenic mycobacterium could cause disseminated infection in immunocompetent individuals, we focused on IFN- $\gamma$ dependent immunity, which is essential for the control of mycobacterial infections. For example, Mendelian susceptibility to mycobacterial disease (MSMD), that leads to paediatric chronic diseases, is a rare condition characterized by susceptibility to weakly virulent mycobacteria, such as Bacille de Calmette et Guérin (BCG) vaccines and environmental mycobacteria [17]. Though MSMD was ruled out in our patient based on her age and the absence of any significant medical history, it is possible that her IFN- $\gamma$ dependent immunity might have been impaired as in an MSMD patient. More detailed studies using the patient's blood cells are needed to confirm this possibility.

Therefore, to the best of our knowledge, our case is the first report suggesting the pathogenicity of $M$. phlei and its ability to cause a disseminated "non-pathogenic" NTM infection in hosts carrying anti-IFN- $\gamma$ autoantibodies. However, what causes an individual to have anti-IFN- $\gamma$ autoantibodies is not clear. If it is related to environmental mycobacterial infections, its clinical significance could be much higher because M. phlei is also used for the treatment of conditions such as asthma.

\section{Abbreviations \\ QFT: QuantiFERON-Gold in tube ; AIDS: Acquired immune deficiency syndrome; AMK: Amikacin; BCG: Bacille de Calmette et Guérin; CA19- 9: Carbohydrate antigen 19-9; CAM: Clarithromycin; CAPD: Continuous ambulatory peritoneal dialysis; CEA: Carcinoembryonic antigen; CFX: Cefoxitin; CPFX: Ciprofloxin; CRP: C-reactive protein; CYFRA: Cytokeratin 19 fragment; DM: Diabetes mellitus; DOXY: Doxycycline; EB: Ethambutol; ESR: Erythrocyte sedimentation rate; FDG-PET: Fluorodeoxyglucose-positron emission tomography; FSGS: Focal and segmental glomerulosclerosis; HIV: Human immunodeficiency virus; HRCT: High-resolution computed tomography; HT: Hypertension; HTLV-1: Human T-cell leukemia virus type 1; ICM: Ischemic cardiomyopathy; IFN- $\gamma$ : Interferon gamma; IgG: Immunoglobulin G; INH: Isoniazid; LVFX: Levofloxacin; $M$. phlei: Mycolicibacterium phlei; MAC: Mycobacterium avium complex; MRI: Magnetic Resonance Imaging; MSMD: Mendelian susceptibility to mycobacterial disease; N/A: Not available; NSE: Nerve specific enolase; NTM: Non-pathogenic nontuberculous mycobacterium; NYHA: New York Heart Association; PCT: Procalcitonin; PHA SI: The lymphocyte phytohemagglutinin (PHA) stimulation index; PHA: Phytohemagglutinin; Pro GRP: Pro-gastrin releasing peptide; RFP: RifampinSMStreptomycin; SCC: Squamous Cell Carcinoma; sIL-2R: Soluble interleukin-2 receptor; TBLB1: Transbronchial lung biopsies; WBC: White blood cell count}

\section{Acknowledgements}

None

\section{Funding}

This work was in part supported by a grant from the Japan Agency for Medical Research and Development/Japan International Cooperation Agency (AMED) to Y. Hoshino (jp18fk0108043, jp18fk0108064, jp18fk0108075, and jp18jm0510004, by Grants-in-Aid for Scientific Research (C) from the Japan Society for the Promotion of Science (JSPS) to Y. Hoshino (jp18K08312), and by Grants-in-Aid for Early-Career Scientists to H. Fukano (jp18K15966). The funders had no role in study design, data collection, and analysis, decision to publish, or preparation of the manuscript.

\section{Availability of data and materials}

Not applicable

\section{Authors' contributions}

ST, YH, TS, HF, YM and $\mathrm{OH}$ constructed the conception and design of this case report. TS examined anti-IFN- $\gamma$ autoantibodies. YH and HF analyzed the DNA of the mycobacterium. ST, YM and $\mathrm{OH}$ treated the patient together and analyzed the clinical data.

All authors read and approved the final manuscript.

\section{Authors' information}

Nothing.

Ethics approval and consent to participate

Not applicable

\section{Consent for publication}

Written informed consent was obtained from the patient for publication of this case. report and the accompanying images.

\section{Competing interests}

The authors declare that they have no competing interests.

\section{Publisher's Note}

Springer Nature remains neutral with regard to jurisdictional claims in published maps and institutional affiliations.

\section{Author details}

${ }^{1}$ Otsu City Hospital, 2-9-9, Motomiya, Otsu-city, Shiga Prefecture, Japan. ${ }^{2}$ Leprosy Research Centre, National Institute of Infectious Diseases, 4 Chome-2-1 Aobacho, Higashimurayama, Tokyo, Japan. ${ }^{3}$ Department of Respiratory Medicine, Faculty of Life Sciences, Kumamoto University, 1-1-1 Honjo, Chuo-ku, Kumamoto, Japan.

Received: 9 January 2019 Accepted: 30 April 2019

Published online: 22 May 2019

References

1. Browne SK, Burbelo PD, Chetchotisakd P, Suputtamongkol $Y$ Kiertiburanakul S, Shaw PA, Kirk JL, Jutivorakool K, Zaman R, Ding L, et al. Adult-onset immunodeficiency in Thailand and Taiwan. N Engl J Med. 2012:367(8):725-34

2. Aguilar JL, Sanchez EE, Carrillo C, Alarcon GS, Silicani A. Septic arthritis due to Mycobacterium phlei presenting as infantile Reiter's syndrome. J Rheumatol. 1989;16(10):1377-8.

3. Spiegl PV, Feiner CM. Mycobacterium phlei infection of the foot: a case report. Foot Ankle Int. 1994;15(12):680-3.

4. Paul E, Devarajan P. Mycobacterium phlei peritonitis: a rare complication of chronic peritoneal dialysis. Pediatr Nephrol. 1998;12(1):67-8

5. Karnam S, Alla VM, Kwon J, Harbert T, Sharma A, Airey K, Mooss A. Mycobacterium phlei, a previously unreported cause of pacemaker infection: thinking outside the box in cardiac device infections. Cardiol J. 2011;18(6):687-90

6. Shojaei H, Heidarieh P, Hashemi A, Feizabadi MM, Daei Naser A. Species identification of neglected nontuberculous mycobacteria in a developing country. Jpn J Infect Dis. 2011;64(4):265-71.

7. Lima CA, Gomes HM, Oelemann MA, Ramos JP, Caldas PC, Campos CE, Pereira MA, Montes FF, Oliveira Mdo S, Suffys PN, et al. Nontuberculous mycobacteria in respiratory samples from patients with pulmonary tuberculosis in the state of Rondonia, Brazil. Mem Inst Oswaldo Cruz. 2013; 108(4):457-62.

8. Khatter S, Singh UB, Arora J, Rana T, Seth P. Mycobacterial infections in human immuno-deficiency virus seropositive patients: role of nontuberculous mycobacteria. Indian J Tuberc. 2008;55(1):28-33.

9. Zhang J, Li C, Guo S. Effects of inhaled inactivated Mycobacterium phlei on airway inflammation in mouse asthmatic models. J Aerosol Med Pulm Drug Deliv. 2012;25(2):96-103. 
10. Kitada S, Kobayashi K, Ichiyama S, Takakura S, Sakatani M, Suzuki K, Takashima T, Nagai T, Sakurabayashi I, Ito M, et al. Serodiagnosis of Mycobacterium avium-complex pulmonary disease using an enzyme immunoassay kit. Am J Respir Crit Care Med. 2008;177(7):793-7.

11. Shima K, Sakagami T, Tanabe Y, Aoki N, Moro H, Koya T, Kagamu H, Hasegawa T, Suzuki E, Narita I. Novel assay to detect increased level of neutralizing anti-interferon gamma autoantibodies in non-tuberculous mycobacterial patients. J Infect Chemother. 2014;20(1):52-6.

12. Hase I, Morimoto K, Sakagami T, Kazumi Y, Ishii Y, van Ingen J. Disseminated Mycobacterium gordonae and Mycobacterium mantenii infection with elevated anti-IFN-gamma neutralizing autoantibodies. J Infect Chemother. 2015;21(6):468-72.

13. Runyon EH. Anonymous mycobacteria in pulmonary disease. Med Clin North Am. 1959;43(1):273-90.

14. Diagnosis and treatment of disease caused by nontuberculous mycobacteria. This official statement of the American Thoracic Society was approved by the Board of Directors, March 1997. Medical section of the American Lung Association. Am J Respir Crit Care Med 1997, 156(2 Pt 2):S1-25

15. Beltan $E$, Horgen $L$, Rastogi N. Secretion of cytokines by human macrophages upon infection by pathogenic and non-pathogenic mycobacteria. Microb Pathog. 2000;28(5):313-8.

16. Raynaud C, Etienne G, Peyron P, Laneelle MA, Daffe M. Extracellular enzyme activities potentially involved in the pathogenicity of Mycobacterium tuberculosis. Microbiology. 1998;144(Pt 2):577-87.

17. Bustamante J, Boisson-Dupuis S, Abel L, Casanova JL. Mendelian susceptibility to mycobacterial disease: genetic, immunological, and clinical features of inborn errors of IFN-gamma immunity. Semin Immunol. 2014; 26(6):454-70.

Ready to submit your research? Choose BMC and benefit from:

- fast, convenient online submission

- thorough peer review by experienced researchers in your field

- rapid publication on acceptance

- support for research data, including large and complex data types

- gold Open Access which fosters wider collaboration and increased citations

- maximum visibility for your research: over $100 \mathrm{M}$ website views per year

At $\mathrm{BMC}$, research is always in progress.

Learn more biomedcentral.com/submissions 